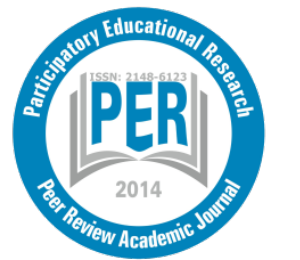

Participatory Educational Research (PER)

Vol. 7(2), pp. 115-134, August 2020

Available online at http://www.perjournal.com

ISSN: 2148-6123

http://dx.doi.org/10.17275/per.20.23.7.2

\title{
Opinions of Prospective Biology Teachers about "Outdoor Learning Environments": The Case of Museum Visit and Scientific Field Trip
}

\author{
Nurcan UZEL* \\ Department of Biology Education, Gazi University, Ankara, Turkey \\ ORCID ID: http://orcid.org/0000-0001-5334-0103
}

\begin{tabular}{|c|c|}
\hline Article history & This study aims to determine the opinions of prospective biology \\
\hline $\begin{array}{l}\text { Received: } \\
19.02 .2020\end{array}$ & $\begin{array}{l}\text { teachers about outdoor learning environments by drawing on the cases } \\
\text { of museum visit and scientific field trip. In line with this aim, }\end{array}$ \\
\hline $\begin{array}{l}\text { Received in revised form: } \\
20.04 .2020\end{array}$ & $\begin{array}{l}\text { phenomenology research design was utilized. Criterion sampling, which } \\
\text { is one of the purposeful sampling methods used in qualitative research } \\
\text { studies. was resorted to with a view to determining the participants. In }\end{array}$ \\
\hline $\begin{array}{l}\text { Accepted: } \\
25.04 .2020\end{array}$ & $\begin{array}{l}\text { accordance with the phenomenology of the research, } 17 \text { prospective } \\
\text { biology teachers in their first year of their studies during 2018-2019 }\end{array}$ \\
\hline Key words: & academic year in a public university constituted the participants of the \\
\hline $\begin{array}{l}\text { Outdoor learning } \\
\text { environments, museum, } \\
\text { scientific field trip, teacher } \\
\text { education, biology education }\end{array}$ & $\begin{array}{l}\text { research. In order to determine the opinions of prospective biology } \\
\text { teachers about outdoor learning environments, an opinion form and an } \\
\text { observation form were made use of as data collection tools. Content } \\
\text { analysis was referred to in the analysis of research data. In their views } \\
\text { on the contributions of the outdoor learning environments, prospective } \\
\text { teachers seemed to concentrate on the issues of gaining new information, } \\
\text { concretizing the knowledge, learning in the natural environment, and } \\
\text { learning by doing and living. It was understood that the codes of } \\
\text { "following the guide/teacher", "acting in a planned manner" and } \\
\text { "practice" came to the fore in the opinions of the prospective biology } \\
\text { teachers regarding the things to be done during the implementation phase } \\
\text { of the outdoor learning environments. While the codes of "getting } \\
\text { opinion" and "question-answer method" came into prominence in the } \\
\text { prospective teachers' views on the things to be done in the evaluation of } \\
\text { outdoor learning environments; especially due to its content, after the } \\
\text { scientific field trip, prospective teachers expressed opinions about "the } \\
\text { examination of the notes taken, pictures, samples, and so on." It was also } \\
\text { observed that codes emerged from the suggestions of prospective } \\
\text { biology teachers regarding the use of outdoor learning environments } \\
\text { focused more on these aspects of the process: "should be a well-planned } \\
\text { trip", "should be informative", "time management" and "participant/ } \\
\text { teacher characteristics". }\end{array}$ \\
\hline
\end{tabular}

\section{Introduction}

The term of learning environment has expanded with different aspects, as in many concepts, in parallel with the rapid change in the field of science and technology. Accordingly, while learning environments were considered primarily within the boundaries of school and classroom, they seemingly have extended in such a way that they begin to include outdoor

\footnotetext{
*Correspondence: nurcanuzel@gazi.edu.tr
} 
environments (Erten \& Taşçi, 2016). Outdoor learning (informal learning) includes experts and/or educators who motivate individuals and is defined as the learning with the help of certain organizations such as non-governmental organizations, public education centers, institutes, youth clubs, and others that assist learners in comprehending events and situations, in particular problems. Experts in this definition refer not only to those with a professional diploma, but also to anyone who has adequate knowledge on any subject, such as parents, friends, and neighbours. Thusly the process can briefly be defined as "helping the individual learn" (Türkmen, 2010). In this regard, outdoor learning environments provide a lot more opportunities for students in terms of learning as they do not limit learners or learning to the classroom environment.

Today, the emphasis on the importance of education catering to individual differences of students is dealt with in a fair number of studies. Yet it is worth underlining here that environments with rich stimuli are assumed to be more effective in meeting varying learningteaching needs. The environment in which these needs will be met can be a classroom as well as an out-of-school environment (Malkoç \& Kaya, 2015). Physical contact provides students with an opportunity for experiential learning. Besides seeing and hearing the natural and cultural phenomena; it also provides experience by smelling, feeling, tasting, and touching (Szczepanski, Malmer, Nelson, \& Dahlgren, 2007). Well-planned and effectively delivered outdoor education offers students chances of improving their knowledge and skills in a way that adds value to their daily experiences in the classroom (Dillon et al., 2006). Students can benefit from learning environments that they can evaluate according to their individual differences. Thus, enhancing the overall process of learning can be supported with education that goes beyond the environments that may be limiting the individual.

Outdoor education is an academic discipline and a teaching method characterized by being engaged with experiential learning, being in nature and doing interesting activities (Nicol, 2002). It covers a very large area consisting of out of lesson/class/school practices and activities within the scope of education; trip-observations and field studies, trips and visits to places carrying social, cultural, industrial and scientific functions, virtual reality applications, nature trainings, environmental club activities, completing homework and projects directly related to the place, sports activities, social, cultural and scientific programs, and spatial applications for lifelong learning (Fidan, 2012). In fact, outdoor learning environments spreading to such a wide area provide a great opportunity for learning.

It is possible to mention alternative out-of-school environments exploited for educational purposes. As an illustration, museums are considered as important institutions that transfer all the heritage of living or non-living civilizations to new generations (Bülbül, 2016). Aktın (2017) determined in her study on a museum trip that children used their own prior knowledge in describing the socio-cultural elements of the past and in explaining the functions of the tools in the museum, and spotted evidence of culture in their personal life experiences. Thomas (2015) argues that practical fieldwork is the basic pedagogy of outdoor education, the main elements of which are a student-centered experiential pedagogy, transition from participant to teacher, and reflection. Studies show that teaching outside the classroom increases student curiosity, fosters collaborative learning, and offers opportunities for authentic science learning (Braund \& Reiss, 2006).

Today, the usage areas of outdoor education are on the increase both in the world and in Turkey. When the outdoor education practices are examined, it is seen that outdoor education is used in sports activities as well as science-related and social issues (Okur-Berberoğlu \& Uygun, 2013). 
Considering the subjects of science education, biology education offers many options particularly in terms of outdoor learning environments. Biology can be taught in any living environment as it focuses on all kinds of information about living things. Whence learning environments where students can concretize their soft information and make observations can be of use in that sense. According to Arianti and Aminatun (2019), outdoor education is a learning method in which detailed and careful observations are made with the fact that biology subjects are based directly on the environment. It indeed gives students the opportunity to transfer their observations directly to paper. Similarly, as to environmental education, outdoor learning environments can offer students the opportunity to experiment with what they learn from books in nature. In parallel to that, Çavuş, Umdu Topsakal, and Öztuna Kaplan (2013) concluded in their study that informal learning is important as much as formal learning in raising environmental awareness.

By creating appropriate learning environments, it should be ensured that children do not lose their spirit of doing research or their natural curiosity via assuring that questioning skills are developed. As a matter of fact, teachers play a key role in the evaluation of the opportunities outside the school (Tatar \& Bağrıyanık, 2012). Likewise, in their study with primary school teachers, van Dijk-Wesselius et al. (2020) advocated the necessity of interventions to support teachers more in order to use out-of-school learning environments for educational purposes fully. Teachers, who believe in the importance of outdoor learning activities know that they are effective, and also possess the know-how of carrying out such activities and these are the ones who can actually benefit from such activities for educational process (Karamustafaoğlu, Ayvalı, \& Ocak, 2018). Also, Saraç (2017) pronounced that studies on outdoor learning environments in Turkey is generally conducted with descriptive and quantitative/scanning methods and mostly performed on middle school students and teachers. In light of this, the current qualitative study is quite important to reveal the opinions of prospective teachers especially by benefiting from out-of-school learning environments. What is more, it is anticipated that experience gained through out-of-school learning environments that are available during teacher education can be transferred to professional lives of prospective teachers later. Therefore, it is considered highly beneficial for the prospective teachers to experience this sort of learning outside the school before starting their teaching profession, and to adopt the role of student and teacher. Biology education complies with out-of-school learning environment taking into account its very content. Hence, the present study focuses on prospective biology teachers, sheds light to their experiences and it is thought that it can contribute to the existing literature.

In this study, it is aimed to determine the opinions of prospective biology teachers about "outdoor learning environments" by using museum visit and scientific field trip examples. Depending on this aim, answers to the following sub-problems are sought, which are related to the problem statement: "What are the opinions of the prospective biology teachers about 'outdoor learning environments' before and after the museum visit and scientific field trip?":

1. What are their opinions on "the contributions of outdoor learning environments"?

2. What are their opinions on "the things to be done in planning outdoor learning environments"?

3. What are their opinions on "the things to be done in the implementation of outdoor learning environments"?

4. What are their opinions on "the things to be done in the evaluation of outdoor learning environments"?

5. What are their "suggestions for more effective use of outdoor learning environments"? 


\section{Method}

\section{Research design}

In this study, phenomenology, as a qualitative research approach, was employed. Phenomenological study expresses the common meaning of the experiences of several individuals related to a phenomenon or concept (Creswell, 2013). Phenomenology focuses on cases that are known but for which in-depth and detailed information is still missing. It includes cases that may be encountered in daily life yet are not fully understood (Yıldırım \& Şimşek, 2013). The researcher collects data from individuals who has experiences related to the phenomenon and provides a holistic explanation about the essence of all individuals' experiences (Moustakas, 1994). In this study, phenomenology design was selected since the opinions of the prospective biology teachers on outdoor learning environments will be determined as regards visits to museum and scientific field trip experiences.

\section{Participants}

Criterion sampling, which is one of the purposeful sampling methods used in qualitative research studies, was employed to identify the participants. In a study, people with certain qualifications, events, objects or situations can form the observation units and units such as objects, events and others that meet the specified criteria constitute the sample (Büyüköztürk et al., 2012). In this type of sampling, criterion or criteria can be created by the researcher or a previously prepared list of criteria can be used (Yıldırım \& Şimşek, 2013). The criterion determined within the scope of this research is that participants are prospective biology teachers who do not have any previous experience with the aforementioned two out-of-school learning environments (Şehit Cuma Dağ Natural History Museum, scientific field trip stations). Thusly, in accordance with the phenomenology of the research, prospective biology teachers who are in their first year of study in the 2018-2019 academic year in a public university are the participants of the research. To be more specific, the study was conducted with 17 pre-service teachers, and two of the students from the potential participant group could not attend the trips due to their health issues and special conditions. Three of the prospective teachers between the ages of 19-21 are male and the remaining 14 are female. To warrant the confidentiality of the identities prospective teachers involved in the study, numbering was carried out independently of the research. To that end, 1st prospective teacher was named as A1, 2nd prospective teacher as $\mathrm{A} 2, \ldots \ldots$ and 17 th prospective teacher as A17.

\section{Data Collection Tools}

The main data collection tool used to determine the opinions of prospective biology teachers about out-of-school learning environments is the opinion form (Appendix 1). A draft form targeting to obtain the opinions of prospective teachers about outdoor learning environments and their expectations alongside suggestions about more effective uses of such trips was prepared by the researcher through examining the previous studies conducted. In line with the opinions and suggestions of three experts who are faculty, the questions were then finalized. For the final form to be created, three prospective biology teachers were consulted about the comprehensibility and applicability of the questions, who did not participate in the research. "Opinion form of prospective biology teachers about outdoor learning environments" consists of 5 open-ended questions. This form was given to prospective teachers three times; first before the trips, second after the museum visit, and third after the scientific field trip (Figure 1) so that the statements in the questions could be arranged according to the type of the trip. For instance, the question "What are the contributions of outdoor learning environments 
to you? Please explain with reasons." turns into: "What are the contributions of the museum visit you have made? Please explain with reasons." after the museum visit. Time spent on filling in the forms was determined as 25-35 minutes.

Unstructured natural environment observation was conducted in order to support the data obtained from the "Opinion form of prospective biology teachers about outdoor learning environments". In this type of observation, the researcher joins the environment and the observation takes place in natural environments where the behaviour takes place. Taking notes in observational studies is the most common method of recording, and taking photographs can also be used to record observation data (Yıldırım \& Şimşek, 2013). During the museum visit and scientific field trip, what students were more interested in, at what point they got bored, and behaviours like taking photos, taking notes were observed. Observation notes were kept by the researcher and students were photographed.

Opinion form of prospective biology teachers about outdoor learning environments

\section{MUSEUM VISIT}

Opinion form of prospective biology teachers about outdoor learning environments

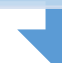

\section{SCIENTIFIC FIELD TRIP}

Opinion form of prospective biology teachers about outdoor learning environments

Figure 1: Schematic representation of the application of opinion forms

\section{Data Collection}

In this study, where the opinions of prospective biology teachers about outdoor learning environments were investigated, trips were organized to two different outdoor learning environments for prospective teachers. The stages followed within the scope of the research are detailed respectively and given below:

- Following the determination of the participants, two areas to be used as outdoor learning environments were chosen, indoor and outdoor areas, both covering the purposes of excursion, observation and education. The first of these was where the museum trip was held: MTA Şehit Cuma Dağ Natural History Museum, located in Ankara. Turkey's first and only natural history museum with international standards, Şehit Cuma Dağ Natural History Museum offers a rich collection (MTA, 2019). The others were the locations determined for the scientific field trip to take place: Kizılcahamam Soğuksu National Park and a stream located in Kızılcahamam-Kırköy. The reason for determining these two stations is to introduce both aquatic and terrestrial ecosystems.

- After determining the outdoor learning environments, the dates of the trips were planned carefully considering the weather conditions, and necessary permissions were obtained from the university. After obtaining the permissions, an appointment was made at MTA Şehit Cuma Dağ Natural History Museum. 
- The prospective teachers were given an opinion form prior to the trips to see their initial views about outdoor learning environments. It took approximately 8-10 minutes for the participants to fill the form.

- Researcher presented outdoor learning environments and voiced their importance in biology education in a session held before the trips. Later, students were informed about MTA Şehit Cuma Dağ Natural History Museum, to where first trip was organized.

- The museum trip was taken in the planned week. Prospective teachers first visited the museum with an expert guide working there. Later, they explored the museum, with the researcher. Students were also given time again to take photos, examine and observe the surroundings individually or as a group. At the end of the museum visit, students were given an opinion form, and it took about 25-30 minutes for them to fill in the forms. Some photos of the trip to the museum are shared in Figure 2 by obtaining the necessary permissions from the individuals.
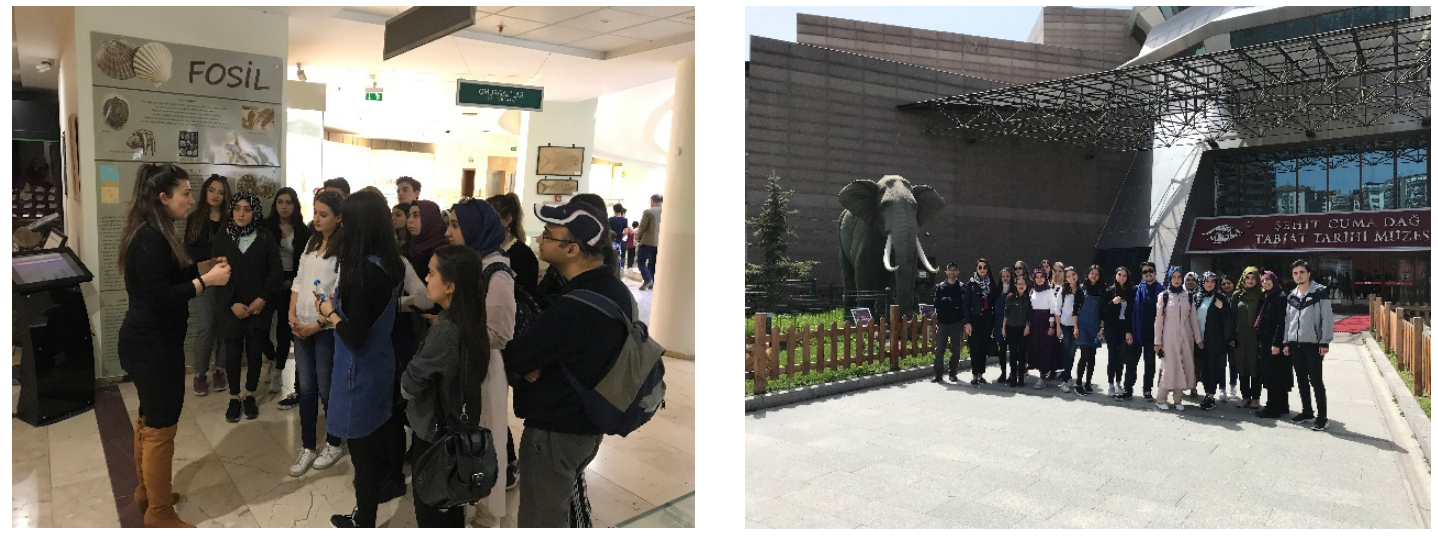

Figure 2. Photos from the museum visit

- The scientific field trip was held the week after the museum visit. The necessary equipment was prepared with the students one day before the field trip, and information was given about the field work process. During the field study, a flora and a fauna expert guided the students. After the field trip was completed, students were given the opinion form, and they filled the forms in about 30-35 minutes. Some of the photographs from the scientific field trip are given in Figure 3, as permission was obtained from the individuals.
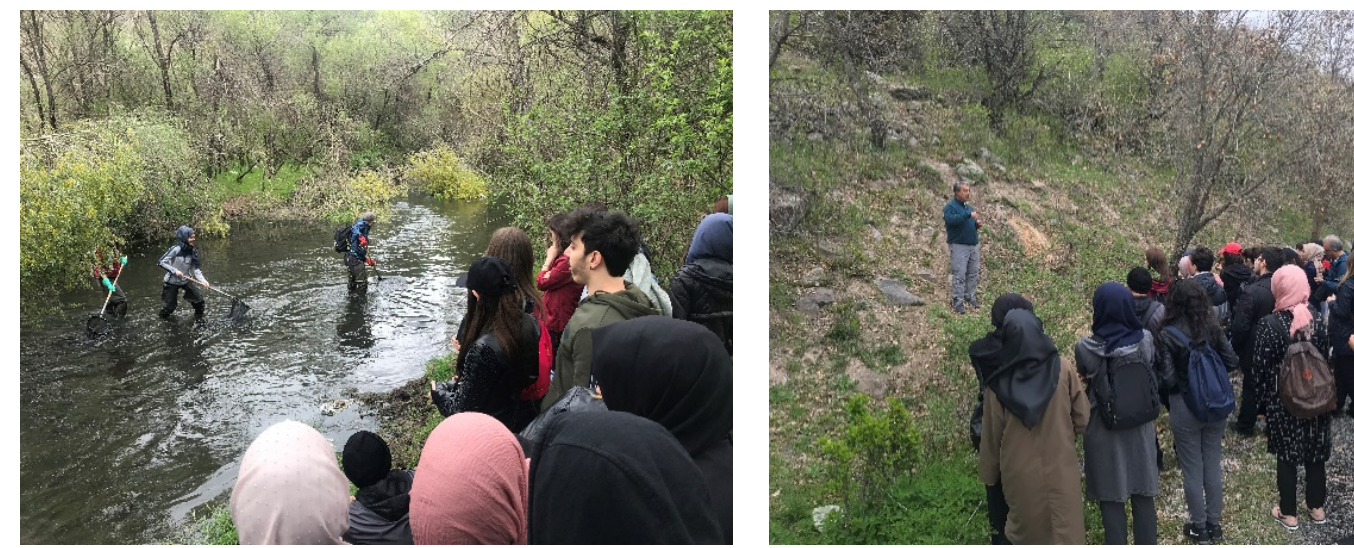

Figure 3. Photos from the scientific field trip 


\section{Data Analysis}

Content analysis was used in the analysis of research data. The basic process step in content analysis is to collect similar data and interpret them under specific concepts and themes (Yıldırım \& Şimşek, 2013). This type of analysis is used in the conversion of the content of a text or document into numerical or statistical data (Ekiz, 2013). Reliability of the analysis of data obtained from prospective biology teachers' opinion forms was calculated using the formula Consensus/(Consensus+Disagreement)x100 (Miles \& Huberman, 1994). The researcher and an expert coded independently and the reliability among the coders was calculated as $88 \%$. In addition, frequencies, direct quotations and photographs were used in the presentation of the data.

\section{Validity and Reliability}

In qualitative research, the internal validity is related to the categories created by the researcher and to the interpretations that overlap with the existing situations and reflect the situations as they are (Yıldırım \& Şimşek, 2013). Long-term interaction, deep-focus data collection, diversification and expert review strategies were used for the internal validity of this research. During the study, the fact that the researcher, who also taught prospective biology teachers, knew the students in advance helped her develop a good rapport with them which enabled the participants to feel comfortable while filling out the forms. Also, as the researcher had previous studies with qualitative design she had the experience in collecting, evaluating and interpreting data of deep-focus nature. Furthermore, the use of opinion forms and observations in data collection diversified the data. The draft opinion form prepared for the expert review strategy was finalized as a result of the examination of three field experts, which again contributed to the quality of the research.

For the transferability of the research, purposive sampling method was employed to determine the participants. Additionally, the transferability of the study was strengthened by explaining the participants, data collection tools, data analysis and data collection process in detail. In qualitative research, the validity of the findings increases as the detailed description of the environment by the researchers makes the data to become more realistic and richer (Creswell, 1994).

In order to ensure the consistency of the results obtained from the data, the reliability among the coders was calculated (88\%). In addition, the data obtained from the opinion forms were supported by direct quotations from the prospective teachers' statements and observation notes and photos taken by the researcher.

\section{Findings}

This section involves the results of the opinions of prospective biology teachers on "outdoor learning environments" before and after the museum visit and scientific field trip as a result of the analyses made in line with the sub-problems identified.

\section{Findings Related to the First Sub-Problem of the Research}

The results of the content analysis regarding the sub-problem asking, "What are the opinions of prospective biology teachers about the contributions of outdoor learning environments before and after the museum visit and scientific field trip?" are given in Table 1. 
Table 1. Content analysis results obtained from prospective biology teachers' opinions about the contributions of outdoor learning environments

\begin{tabular}{|c|c|c|c|c|c|c|}
\hline \multirow{2}{*}{ Codes } & \multicolumn{2}{|l|}{ Before the trips } & \multicolumn{2}{|l|}{ After the museum visit } & \multicolumn{2}{|c|}{ After the scientific field trip } \\
\hline & Prospective teachers & f & Prospective teachers & f & \begin{tabular}{|l} 
Prospective teachers \\
\end{tabular} & f \\
\hline Gaining new information & A1, A7, A9 & 3 & $\begin{array}{l}\text { A1, A3, A5, A6, A8, A9, } \\
\text { A12, A15, A16, A17 }\end{array}$ & 10 & $\begin{array}{c}\text { A1, A2, A4, A6, A7, A9, } \\
\text { A11, A12, A16 }\end{array}$ & 9 \\
\hline Observation & A3, A12 & 2 & $\mathrm{~A} 8, \mathrm{~A} 9, \mathrm{~A} 12, \mathrm{~A} 13, \mathrm{~A} 14$ & 5 & $\begin{array}{c}\text { A3, A5, A6, A8, A9, A10, } \\
\text { A12, A14, A15 }\end{array}$ & 9 \\
\hline Permanent learning & $\begin{array}{l}\text { A2, A3, A4, A5, A6, A7, } \\
\text { A9, A11, A14, A15, A17 }\end{array}$ & 11 & $\mathrm{~A} 2, \mathrm{~A} 7, \mathrm{~A} 8, \mathrm{~A} 9, \mathrm{~A} 13$ & 5 & $\mathrm{~A} 3, \mathrm{~A} 4, \mathrm{~A} 9, \mathrm{~A} 13, \mathrm{~A} 17$ & 5 \\
\hline Socializing & $\mathrm{A} 9, \mathrm{~A} 16$ & 2 & $\mathrm{~A} 9, \mathrm{~A} 10$ & 2 & $\mathrm{~A} 4, \mathrm{~A} 10$ & 2 \\
\hline Learning through having fun & A10 & 1 & A6, A9 & 2 & $\mathrm{~A} 10, \mathrm{~A} 14, \mathrm{~A} 15, \mathrm{~A} 17$ & 4 \\
\hline Gaining detailed information & A10 & 1 & $\mathrm{~A} 5, \mathrm{~A} 8, \mathrm{~A} 9, \mathrm{~A} 16, \mathrm{~A} 17$ & 5 & & \\
\hline Gaining a different perspective & A16 & 1 & $\mathrm{~A} 9, \mathrm{~A} 10, \mathrm{~A} 12, \mathrm{~A} 15$ & 4 & & \\
\hline $\begin{array}{l}\text { Learning in the natural } \\
\text { environment }\end{array}$ & $\mathrm{A} 11, \mathrm{~A} 12$ & 2 & & & $\begin{array}{l}\text { A1, A2, A3, A5, A7, A8, } \\
\text { A12, A13, A15, A16, A17 }\end{array}$ & 11 \\
\hline Providing sample diversity & & & $\begin{array}{c}\text { A1, A2, A3, A4, A6, } \\
\text { A7, A8, A9, A11, A12, } \\
\text { A14, A15, A16, A17 }\end{array}$ & 14 & $\begin{array}{c}\text { A2, A5, A6, A7, A8, A9, } \\
\text { A10, A11, A12, A13, A15, } \\
\text { A17 }\end{array}$ & 12 \\
\hline Impressive learning & & & $\begin{array}{c}\text { A1, A2, A3, A4, A5, } \\
\text { A7, A8, A9, A10, A11, } \\
\text { A12, A13, A15, A17 }\end{array}$ & 14 & $\mathrm{~A} 4, \mathrm{~A} 14, \mathrm{~A} 17$ & 3 \\
\hline Being a teacher & & & $\mathrm{A} 2, \mathrm{~A} 10, \mathrm{~A} 11, \mathrm{~A} 13$ & 4 & $\mathrm{~A} 10$ & 1 \\
\hline New experiences & & & $\begin{array}{c}\mathrm{A} 5, \mathrm{~A} 6, \mathrm{~A} 9, \mathrm{~A} 10, \mathrm{~A} 11, \\
\mathrm{~A} 12, \mathrm{~A} 17 \\
\end{array}$ & 7 & $\begin{array}{c}\mathrm{A} 1, \mathrm{~A} 2, \mathrm{~A} 4, \mathrm{~A} 6, \mathrm{~A} 9, \mathrm{~A} 10, \\
\mathrm{~A} 15, \mathrm{~A} 16\end{array}$ & 8 \\
\hline $\begin{array}{l}\text { Concretization of the } \\
\text { information }\end{array}$ & & & $\begin{array}{l}\text { A2, A3, A4, A7, A8, } \\
\text { A9, A11, A12, A13, } \\
\text { A14, A15, A17 }\end{array}$ & 12 & $\begin{array}{l}\mathrm{A} 1, \mathrm{~A} 2, \mathrm{~A} 4, \mathrm{~A} 5, \mathrm{~A} 6, \mathrm{~A} 8 \\
\mathrm{~A} 9, \mathrm{~A} 11, \mathrm{~A} 14, \mathrm{~A} 16, \mathrm{~A} 17\end{array}$ & 11 \\
\hline Learning by seeing & $\begin{array}{l}\text { A2, A5, A6, A7, A8, } \\
\text { A9, A13, A14 }\end{array}$ & 8 & & & & \\
\hline Experiencing the information & $\begin{array}{c}\text { A4, A5, A8, A9, A10, } \\
\text { A15, A17 }\end{array}$ & 7 & & & & \\
\hline Confirming the information & A1, A16 & 2 & & & & \\
\hline Facilitated learning & A10 & 1 & & & & \\
\hline Learning by doing and living & & & & & $\begin{array}{l}\text { A1, A2, A3, A4, A5, A9, } \\
\text { A10, A12, A14, 16, } 17\end{array}$ & 11 \\
\hline
\end{tabular}

According to the codes obtained from the opinions of the prospective biology teachers about the contributions of outdoor learning environments, the code of "permanent learning" ( $f=11)$ before the trips; the codes of "providing sample diversity" ( $\mathrm{f}=14)$ and "impressive learning" $(\mathrm{f}=14)$ after the museum visit; the code of "providing sample diversity" ( $\mathrm{f}=12)$ after the scientific field trip were determined to have the highest frequency. When evaluated in general, it was determined that the codes obtained from the opinions of prospective teachers before the trips had lower frequencies. After the museum visit, it was observed that the prospective teachers emphasized such issues as gaining new information $(\mathrm{f}=10)$ and concretizing the information $(\mathrm{f}=12)$. After the scientific field trip, it was understood that they focused on the issues of learning in the natural environment $(\mathrm{f}=11)$ and learning by doing and living $(\mathrm{f}=11)$ along with the concretization of the information ( $\mathrm{f}=11)$. At this point, one of the most striking findings is that, especially after the museum visit, the prospective teachers made inferences about the teaching they will carry out when they graduate. Some of the expressions used by the prospective teachers regarding the most frequently used codes are given below.

- What I have learned in outdoor learning environments is more permanent. Because what I see takes place in my memory more than what is told, that is, it becomes more permanent (A2, permanent learning, before trips).

- I like the science tunnel on the top floor. It felt like it was passing through the fish. It was very lively and realistic, I was very impressed (A6, impressive learning, after the museum trip). 
- We had the chance to see many fossils, living patterns, natural stones, the objects used by people who lived in ancient times, the paintings they drew on the walls of the cave, the age rings of a tree ... and many other things (A3, providing sample diversity, after the museum trip).

- We saw how the fish sample, water and mud sample should be collected. We learned about the flowers and properties of plants (A4, providing sample diversity, after the scientific field trip).

\section{Findings Related to the Second Sub-Problem of the Research}

The results of the content analysis regarding the sub-problem asking, "What are the opinions of the prospective biology teachers about the things to be done during the planning of outdoor learning environments before and after the museum visit and scientific field trip?" are given in Table 2 .

Table 2. Content analysis results obtained from prospective biology teachers' opinions on the things to be done during the planning of outdoor learning environments

\begin{tabular}{|c|c|c|c|c|c|c|}
\hline \multirow{2}{*}{ Codes } & \multicolumn{2}{|l|}{ Before the trips } & \multicolumn{2}{|l|}{ After the museum visit } & \multicolumn{2}{|c|}{ After the scientific field trip } \\
\hline & Prospective teachers & f & Prospective teachers & f & Prospective teachers & f \\
\hline Planning the trip & $\mathrm{A} 1, \mathrm{~A} 2$ & 2 & $\mathrm{~A} 1, \mathrm{~A} 2, \mathrm{~A} 4, \mathrm{~A} 6, \mathrm{~A} 9, \mathrm{~A} 10$ & 6 & $\mathrm{~A} 1, \mathrm{~A} 2, \mathrm{~A} 4, \mathrm{~A} 5, \mathrm{~A} 6, \mathrm{~A} 10$ & 6 \\
\hline Making the list of participants & A3 & 1 & $\begin{array}{c}\mathrm{A} 3, \mathrm{~A} 8, \mathrm{~A} 9, \mathrm{~A} 11, \mathrm{~A} 12, \\
\mathrm{~A} 17\end{array}$ & 6 & $\mathrm{~A} 3, \mathrm{~A} 5, \mathrm{~A} 11, \mathrm{~A} 13, \mathrm{~A} 14$ & 5 \\
\hline Selection of the place & $\begin{array}{l}\text { A4, A5, A10, A11, } \\
\text { A14, A16, A17 }\end{array}$ & 7 & A9, A10, A12 & 3 & $\mathrm{~A} 5, \mathrm{~A} 13, \mathrm{~A} 14, \mathrm{~A} 15$ & 4 \\
\hline Informing the students & A9, A12, A14 & 3 & $\mathrm{~A} 2, \mathrm{~A} 12, \mathrm{~A} 13, \mathrm{~A} 17$ & 4 & $\begin{array}{c}\text { A1, A2, A4, A5, A6, A7, } \\
\text { A12, A13, A17 }\end{array}$ & 9 \\
\hline $\begin{array}{l}\text { Obtaining information on the } \\
\text { place to be visited }\end{array}$ & $\mathrm{A} 6, \mathrm{~A} 7, \mathrm{~A} 8, \mathrm{~A} 10$ & 4 & $\mathrm{~A} 2, \mathrm{~A} 3, \mathrm{~A} 12$ & 3 & $\mathrm{~A} 2, \mathrm{~A} 3, \mathrm{~A} 5, \mathrm{~A} 17$ & 4 \\
\hline Selection of the date & A16 & 1 & A9, A14 & 2 & $\begin{array}{c}\text { A4, A5, A9, A10, A11, } \\
\text { A13, A17 }\end{array}$ & 7 \\
\hline Arranging the guide & $\mathrm{A} 3, \mathrm{~A} 8$ & 2 & $\mathrm{~A} 1, \mathrm{~A} 2$ & 2 & & \\
\hline Making appointment & A5 & 1 & A5, A14 & 2 & & \\
\hline Getting the students prepared & A16, A17 & 2 & & & $\begin{array}{l}\mathrm{A} 3, \mathrm{~A} 4, \mathrm{~A} 7, \mathrm{~A} 8, \mathrm{~A} 9, \mathrm{~A} 10, \\
\mathrm{~A} 11, \mathrm{~A} 14, \mathrm{~A} 15, \mathrm{~A} 16\end{array}$ & 10 \\
\hline Preparing the equipment & $\mathrm{A} 3, \mathrm{~A} 15, \mathrm{~A} 16, \mathrm{~A} 17$ & 4 & & & $\begin{array}{c}\text { A3, A4, A8, A9, A11, } \\
\text { A12, A14, A15, A16 }\end{array}$ & 9 \\
\hline Obtaining permission & & & $\begin{array}{c}\text { A3, A4, A5, A6, A7, A8, } \\
\text { A9, A11, A12, A14, A15, } \\
\text { A16, A17 }\end{array}$ & 13 & $\begin{array}{c}\mathrm{A} 2, \mathrm{~A} 3, \mathrm{~A} 4, \mathrm{~A} 5, \mathrm{~A} 8, \mathrm{~A} 9, \\
\mathrm{~A} 10, \mathrm{~A} 11, \mathrm{~A} 12, \mathrm{~A} 14, \mathrm{~A} 15, \\
\mathrm{~A} 16, \mathrm{~A} 17\end{array}$ & 13 \\
\hline Arranging the vehicle & & & $\begin{array}{l}\mathrm{A} 3, \mathrm{~A} 5, \mathrm{~A} 8, \mathrm{~A} 9, \mathrm{~A} 11, \\
\mathrm{~A} 15, \mathrm{~A} 16, \mathrm{~A} 17\end{array}$ & 8 & $\begin{array}{c}\text { A2, A3, A4, A5, A8, A9, } \\
\text { A10, A11, A12, A14, A15, } \\
\text { A16, A17 }\end{array}$ & 13 \\
\hline Knowing the curriculum & A13 & 1 & & & & \\
\hline
\end{tabular}

When the codes obtained from the opinions of the prospective biology teachers about the things to be done at the planning stage of outdoor learning environments were examined, it was understood that the frequencies of the code of "selection of the place" $(f=7)$ before the trips; the code of "obtaining permission" ( $\mathrm{f}=13$ ) after the museum visit; "obtaining permissions" ( $\mathrm{f}=13$ ) and "arranging the vehicle" ( $\mathrm{f}=13)$ codes after the scientific field trip were the highest. It was determined that the codes obtained from the opinions of the prospective teachers were quite similar before and after the trips, but the frequencies before the trip were lower. After the museum visit and scientific field trip, it was witnessed that the prospective teachers gave priority to issues such as "obtaining permission" and "arranging the vehicle" during the planning phase. After the scientific field trip, preparations such as "informing the students" $(\mathrm{f}=9)$, "getting the students prepared" $(\mathrm{f}=10)$, and "preparing the equipment" $(\mathrm{f}=9)$ were seen to be prioritized. Some examples of the expressions regarding the codes most frequently used by prospective teachers are given below.

- $\quad$ The place to go is decided on the topic of the subject (A5, selection of the place, before the trip). 
- $\quad$ The petition approved by the Biology Education Department is signed by the Department of Mathematics and Science. Then goes to the Dean's Office and the Rector's Office (A16, obtaining permission, after the museum visit).

- Writing the permission to be obtained for the trip as a petition and having it signed by the authorities (A8, obtaining permission, after the scientific field trip).

- $\quad$ Transportation vehicle is arranged (A10, arranging the vehicle, after the scientific field trip).

- Giving preliminary information about the living samples to be examined and seen (A17, informing the students, after the scientific field trip)

- Students should be instructed to come prepared with appropriate clothing according to weather conditions (A9, getting the students prepared, after the scientific field trip).

- Necessary equipment is provided for the trip (A12, preparing the equipment, after the scientific field trip).

\section{Findings Related to the Third Sub-Problem of the Research}

The results of the content analysis regarding the sub-problem asking, "What are the views of the prospective biology teachers about the things to be done in the implementation of outdoor learning environments before and after the museum visit and scientific field trip?" are given in Table 3.

Table 3. Content analysis results obtained from prospective biology teachers' opinions on the things to be done during the implementation of outdoor learning environments

\begin{tabular}{|c|c|c|c|c|c|c|}
\hline \multirow{2}{*}{ Codes } & \multicolumn{2}{|l|}{ Before the trips } & \multicolumn{2}{|l|}{ After the museum visit } & \multicolumn{2}{|c|}{ After the scientific field trip } \\
\hline & Prospective teachers & f & Prospective teachers & f & Prospective teachers & f \\
\hline Teaching with examples & A1, A17 & 2 & A1, A6, A9, A10, A14, A15 & 6 & $\begin{array}{l}\text { A1, A3, A4, A6, A7, A8, } \\
\text { A9, A12, A13, A14, A17 }\end{array}$ & 11 \\
\hline Following the guide/teacher & $\begin{array}{c}\mathrm{A} 2, \mathrm{~A} 5, \mathrm{~A} 6, \mathrm{~A} 7, \mathrm{~A} 8 \\
\mathrm{~A} 9, \mathrm{~A} 10\end{array}$ & 7 & $\begin{array}{l}\mathrm{A} 1, \mathrm{~A} 2, \mathrm{~A} 3, \mathrm{~A} 6, \mathrm{~A} 7, \mathrm{~A} 9 \\
\mathrm{~A} 11, \mathrm{~A} 12, \mathrm{~A} 13, \mathrm{~A} 14, \mathrm{~A} 17\end{array}$ & 11 & $\begin{array}{l}\mathrm{A} 3, \mathrm{~A} 6, \mathrm{~A} 7, \mathrm{~A} 8, \mathrm{~A} 9, \mathrm{~A} 10, \\
\mathrm{~A} 12, \mathrm{~A} 13, \mathrm{~A} 15, \mathrm{~A} 17\end{array}$ & 10 \\
\hline Acting in a planned manner & $\mathrm{A} 3, \mathrm{~A} 12, \mathrm{~A} 16$ & 3 & $\begin{array}{l}\text { A1, A2, A3, A4, A7, A9, } \\
\text { A10, A11, A12, A13, A16 }\end{array}$ & 11 & $\begin{array}{l}\mathrm{A} 2, \mathrm{~A} 5, \mathrm{~A} 7, \mathrm{~A} 9, \mathrm{~A} 10 \\
\mathrm{~A} 11, \mathrm{~A} 12, \mathrm{~A} 13\end{array}$ & 8 \\
\hline Maintaining discipline & $\mathrm{A} 4, \mathrm{~A} 8, \mathrm{~A} 9, \mathrm{~A} 13, \mathrm{~A} 15$ & 5 & $\begin{array}{c}\text { A4, A5, A8, A11, A12, } \\
\text { A16, A17 }\end{array}$ & 7 & $\begin{array}{c}\mathrm{A} 4, \mathrm{~A} 8, \mathrm{~A} 9, \mathrm{~A} 11, \mathrm{~A} 14, \\
\mathrm{~A} 16, \mathrm{~A} 17\end{array}$ & 7 \\
\hline Taking notes and photos & A4 & 1 & $\mathrm{~A} 4, \mathrm{~A} 10, \mathrm{~A} 14, \mathrm{~A} 15$ & 4 & $\mathrm{~A} 5, \mathrm{~A} 6, \mathrm{~A} 10, \mathrm{~A} 13, \mathrm{~A} 15$ & 5 \\
\hline $\begin{array}{l}\text { Reinforcement of previous } \\
\text { knowledge }\end{array}$ & $\mathrm{A} 10, \mathrm{~A} 11$ & 2 & $\begin{array}{c}\mathrm{A} 2, \mathrm{~A} 7, \mathrm{~A} 8, \mathrm{~A} 9, \mathrm{~A} 14, \mathrm{~A} 15, \\
\mathrm{~A} 17\end{array}$ & 7 & $\begin{array}{c}\mathrm{A} 2, \mathrm{~A} 3, \mathrm{~A} 7, \mathrm{~A} 8, \mathrm{~A} 9, \mathrm{~A} 10, \\
\mathrm{~A} 13, \mathrm{~A} 14\end{array}$ & 8 \\
\hline Observation & $\mathrm{A} 4, \mathrm{~A} 5, \mathrm{~A} 8$ & 3 & $\mathrm{~A} 3, \mathrm{~A} 6, \mathrm{~A} 7, \mathrm{~A} 10$ & 4 & $\mathrm{~A} 6, \mathrm{~A} 13, \mathrm{~A} 14, \mathrm{~A} 17$ & 4 \\
\hline Time management & & & $\mathrm{A} 3, \mathrm{~A} 5, \mathrm{~A} 8, \mathrm{~A} 16$ & 4 & $\mathrm{~A} 3, \mathrm{~A} 5, \mathrm{~A} 8, \mathrm{~A} 16$ & 4 \\
\hline Impressiveness & $\mathrm{A} 14, \mathrm{~A} 16$ & 2 & & & & \\
\hline Collecting samples & A4 & 1 & & & & \\
\hline Allowing free time & & & $\mathrm{A} 2, \mathrm{~A} 3, \mathrm{~A} 9, \mathrm{~A} 14$ & 4 & & \\
\hline Practice & & & & & $\begin{array}{c}\mathrm{A} 1, \mathrm{~A} 2, \mathrm{~A} 4, \mathrm{~A} 6, \mathrm{~A} 7, \mathrm{~A} 8, \\
\mathrm{~A} 9, \mathrm{~A} 10, \mathrm{~A} 11, \mathrm{~A} 13, \mathrm{~A} 14, \\
\mathrm{~A} 17\end{array}$ & 12 \\
\hline Group cohesiveness & & & & & $\begin{array}{c}\mathrm{A} 4, \mathrm{~A} 5, \mathrm{~A} 8, \mathrm{~A} 10, \mathrm{~A} 14, \\
\mathrm{~A} 15\end{array}$ & 6 \\
\hline
\end{tabular}

When the codes emerged from the opinions of the prospective biology teachers about the things to be done during the implementation of the outdoor learning environments were analyzed, the code of "watching the guide/teacher" before the trips $(\mathrm{f}=7)$ and after the museum visit $(\mathrm{f}=11)$ had the highest frequency. Also, the code of "acting in a planned manner" ( $f=11)$ after the museum visit was at the same frequency as the "following the guide/teacher" code. Unlike the others, after the scientific field trip, the code of "practice" ( $f=12)$ was at the highest frequency for the things to be done at the implementation stage. When the above table is analysed, it is understood that the prospective teachers shared opinions about the things to be done during the implementation of the outdoor learning environments specifically after the scientific field trip. That said, "allowing free time" in the museum visit and "group cohesiveness" in the scientific 
field trip were among the prominent results regarding the implementation of these outdoor learning environments. Some examples of the most frequent or prominent expressions from the codes used by prospective teachers are presented below.

- The guide introducing the environment should be paid close attention to (A8, following the guide/teacher, before the trip).

- I think it is very important for an expert to introduce the museum and give information about it during the implementation phase (A13, following the guide / teacher, after the museum visit).

- First of all, the visit should address issues from the beginning (for example, from the formation of the world and from the first creature) (Al, acting in a planned manner, after the museum visit).

- Students can be more active at the implementation stage. For example, one of the students can try fishing or while the plants are examined, information can be given on the plants collected by the students ( $A 2$, practice, after the scientific field trip).

- Free time should be allowed because it will create the opportunity to walk around more (A9, allowing free time, after the museum visit).

- We should act in harmony with the awareness of our own responsibility and the responsibility of the people with us because this is a participation with a community (A8, group cohesiveness, after the scientific field trip).

\section{Findings Related to the Fourth Sub-Problem of the Research}

The results of the content analysis regarding the sub-problem asking "What are the views of the prospective biology teachers about things to be done in the evaluation of outdoor learning environments?" are given in Table 4.

Table 4. Content analysis results obtained from prospective biology teachers' opinions on the things to be done in the evaluation of outdoor learning environments

\begin{tabular}{|c|c|c|c|c|c|c|}
\hline \multirow{2}{*}{ Codes } & \multicolumn{2}{|l|}{ Before the trips } & \multicolumn{2}{|c|}{ After the museum visit } & \multicolumn{2}{|c|}{ After the scientific field trip } \\
\hline & Prospective teachers & $\mathbf{f}$ & Prospective teachers & f & Prospective teachers & $\mathbf{f}$ \\
\hline Question-answer method & $\mathrm{A} 1, \mathrm{~A} 5, \mathrm{~A} 7, \mathrm{~A} 9, \mathrm{~A} 10, \mathrm{~A} 13$ & 6 & $\begin{array}{l}\mathrm{A} 5, \mathrm{~A} 8, \mathrm{~A} 9, \mathrm{~A} 10, \mathrm{~A} 11, \\
\mathrm{~A} 13, \mathrm{~A} 14, \mathrm{~A} 16\end{array}$ & 8 & $\begin{array}{l}\mathrm{A} 1, \mathrm{~A} 4, \mathrm{~A} 7, \mathrm{~A} 8, \mathrm{~A} 9, \mathrm{~A} 11, \\
\mathrm{~A} 13, \mathrm{~A} 14, \mathrm{~A} 15, \mathrm{~A} 16, \mathrm{~A} 17\end{array}$ & 11 \\
\hline Discussion method & $\mathrm{A} 2, \mathrm{~A} 5, \mathrm{~A} 8, \mathrm{~A} 9, \mathrm{~A} 16, \mathrm{~A} 17$ & 6 & $\mathrm{~A} 2, \mathrm{~A} 12, \mathrm{~A} 14, \mathrm{~A} 17$ & 4 & $\mathrm{~A} 2, \mathrm{~A} 5, \mathrm{~A} 10, \mathrm{~A} 13$ & 4 \\
\hline Getting opinion & $\begin{array}{c}\mathrm{A} 1, \mathrm{~A} 3, \mathrm{~A} 5, \mathrm{~A} 7, \mathrm{~A} 8, \mathrm{~A} 9 \\
\mathrm{~A} 10, \mathrm{~A} 14, \mathrm{~A} 15\end{array}$ & 9 & $\begin{array}{c}\text { A3, A4, A5, A6, A7, } \\
\text { A8, A9, A11, A13, A14, } \\
\text { A16, A17 }\end{array}$ & 12 & $\begin{array}{c}\mathrm{A} 2, \mathrm{~A} 3, \mathrm{~A} 4, \mathrm{~A} 5, \mathrm{~A} 6, \mathrm{~A} 8 \\
\mathrm{~A} 9, \mathrm{~A} 10\end{array}$ & 8 \\
\hline Reporting & $\mathrm{A} 12, \mathrm{~A} 15, \mathrm{~A} 17$ & 3 & $\mathrm{~A} 12$ & 1 & $\mathrm{~A} 12, \mathrm{~A} 14, \mathrm{~A} 17$ & 3 \\
\hline $\begin{array}{l}\text { Examination of the notes } \\
\text { taken, pictures, and } \\
\text { samples, etc. }\end{array}$ & $\mathrm{A} 4, \mathrm{~A} 12, \mathrm{~A} 15$ & 3 & $\mathrm{~A} 4, \mathrm{~A} 10, \mathrm{~A} 15$ & 3 & $\begin{array}{l}\text { A4, A6, A8, A10, A12, } \\
\text { A14, A15, A16, A } 17\end{array}$ & 9 \\
\hline Testing & A9, A11 & 2 & & & & \\
\hline Research & & & $\mathrm{A} 1$ & 1 & & \\
\hline
\end{tabular}

According to the codes developed from the opinions of the prospective biology teachers about the things to be done during the evaluation of the outdoor learning environments, it was understood that the code of "getting opinion" was at the highest frequency before the trips $(\mathrm{f}=9)$ and after the museum visit ( $\mathrm{f}=12$ ). Moreover, "question-answer method" ( $\mathrm{f}=11)$ code was found to have the highest frequency for the things to be done in the evaluation phase after the scientific field trip. In general, it was noted that the prospective teachers provided similar answers at each stage when they were asked to share their opinions on the evaluation phase of outdoor learning environments. Especially due to its content, after the scientific field trip, prospective teachers were observed to express opinions through the code of "examination of the notes taken, pictures, and samples, etc." ( $\mathrm{f}=9)$. Some examples of the highest frequency codes or some striking expressions used by prospective teachers are shared below.

- While evaluating, students' personal opinions should be evaluated (A15, getting opinion, before the trip). 
- $\quad$ Opinions and thoughts should be taken in written form or verbally by interviewing the participants (A3, receiving a view, after the museum visit).

- By asking questions to the student, the continuity of the flow of information is ensured (A9, questionanswer method, after the scientific field trip).

- It can be evaluated with the photographs and the grades taken (A15, examination of the notes taken, pictures, and samples, etc., after the scientific field trip).

- It would be a good form of evaluation to talk about the species we have collected and to examine them closely (A6, examination of the notes taken, pictures, and samples, etc., after the scientific field trip).

\section{Findings Related to the Fifth Sub-Problem of the Research}

The results of the content analysis regarding the sub-problem asking, "What are the suggestions of prospective biology teachers for the more effective use of outdoor learning environments before and after the museum and scientific field trip?" are given in Table 5.

Table 5. Content analysis results obtained from prospective biology teachers' opinions on the use of outdoor learning environments more effectively

\begin{tabular}{|c|c|c|c|c|c|c|}
\hline \multirow{2}{*}{ Codes } & \multicolumn{2}{|l|}{ Before the trips } & \multicolumn{2}{|l|}{ After the museum visit } & \multicolumn{2}{|l|}{ After the scientific field trip } \\
\hline & Prospective teachers & $\mathbf{f}$ & Prospective teachers & $\mathbf{f}$ & Prospective teachers & $\mathbf{f}$ \\
\hline General & $\begin{array}{l}\text { Should be gone preparedly } \\
\text { A5, A13 } \\
\text { Should be a well-planned trip } \\
\text { A9, A14 }\end{array}$ & 4 & $\begin{array}{c}\text { Should be a well-planned trip } \\
\text { A2, A3, A4, A5, A6, A8, } \\
\text { A11, A12, A13, A14, A15 } \\
\text { Should be evaluated } \\
\text { A7, A13 }\end{array}$ & 12 & $\begin{array}{c}\text { Should be a well-planned trip } \\
\text { A1, A3, A4, A5, A7, A9, } \\
\text { A10, A12, A13, A14, A15, } \\
\text { A16 } \\
\text { Should be evaluated } \\
\text { A6, A7, A17 }\end{array}$ & 14 \\
\hline Participants & $\mathrm{A} 3, \mathrm{~A} 11, \mathrm{~A} 12, \mathrm{~A} 14, \mathrm{~A} 15, \mathrm{~A} 16$ & 6 & A8, A11 & 2 & $\mathrm{~A} 4, \mathrm{~A} 8, \mathrm{~A} 10, \mathrm{~A} 17$ & 4 \\
\hline Content & $\begin{array}{c}\text { Should be informative } \\
\text { A5, A6, A7, A8, A13, A14, } \\
\text { A17 }\end{array}$ & 7 & $\begin{array}{c}\text { Preliminary info. } \\
\text { A13, A14 } \\
\text { Detailed info. } \\
\text { A1, A2, A3, A9, A11, A12, } \\
\text { A17 }\end{array}$ & 9 & $\begin{array}{c}\text { Preliminary info. } \\
\text { A3, A5, A6, A7, A10, A15, } \\
\text { A17 } \\
\text { Choosing a different station } \\
\text { A1, A3, A17 } \\
\text { Observation and investigation } \\
\text { A2, A3, A5, A7, A9, A10, } \\
\text { A13, A14, A15, A17 }\end{array}$ & 12 \\
\hline $\begin{array}{l}\text { Time } \\
\text { management }\end{array}$ & $\begin{array}{c}\text { Should be done frequently } \\
\text { A1, A4, A8, A9, A10 } \\
\text { Same place should be visited at } \\
\text { least twice } \\
\text { A2 }\end{array}$ & 6 & $\begin{array}{c}\mathrm{A} 1, \mathrm{~A} 3, \mathrm{~A} 5, \mathrm{~A} 9, \mathrm{~A} 10, \mathrm{~A} 12, \\
\text { A16 } \\
\text { Free time } \\
\text { A5, A12 }\end{array}$ & 7 & $\begin{array}{l}\mathrm{A} 2, \mathrm{~A} 4, \mathrm{~A} 8, \mathrm{~A} 9, \mathrm{~A} 15 \\
\text { Selection of date } \\
\mathrm{A} 1, \mathrm{~A} 3, \mathrm{~A} 8, \mathrm{~A} 11\end{array}$ & 8 \\
\hline Guide/Teacher & $\mathrm{A} 3, \mathrm{~A} 6, \mathrm{~A} 7, \mathrm{~A} 8, \mathrm{~A} 12$ & 5 & $\begin{array}{c}\mathrm{A} 1, \mathrm{~A} 3, \mathrm{~A} 8, \mathrm{~A} 9, \mathrm{~A} 10, \mathrm{~A} 11, \\
\mathrm{~A} 15\end{array}$ & 7 & & \\
\hline
\end{tabular}

The codes emerged from the suggestions of the prospective biology teachers regarding the use of outdoor learning environments were divided into five as general, participants, content, time management, guide/teacher. After the museum visit $(\mathrm{f}=12)$ and the scientific field trip $(\mathrm{f}=14)$, the "general" code; and before the trips, the "content" code was detected to have the highest frequency. The "content" code stood out in the opinions obtained after the museum visit and the scientific field trip. One of the remarkable views of the teacher candidates was that the "guide/teacher" code was an issue mentioned before the trips and after the museum visit, whilst it was never used after the scientific field trip. Some examples of the highest frequency codes or striking expressions used by prospective biology teachers in their suggestions for the use of outdoor learning environments are given below.

- Before the trip, brief and clear information should be given, and after going there, this information should be reinforced by adding new information (A7, content, before the trip).

- A good plan must be made for the trip to be effective (A11, general, after the museum visit).

- After the trip, students can assure the permanence of the species learned by asking each other (A6, general, after the scientific field trip). 
- The narration of the guides can be more detailed (A9, content, after the museum visit).

- For the trip to be more effective, the student should execute an application (A10, content, after the scientific field trip).

\section{Discussion, Results, and Suggestions}

In this research, a museum visit and scientific field trips were organized to determine the opinions of prospective biology teachers about outdoor learning environments. Before the trips, "Opinion form of prospective biology teachers about outdoor learning environments" consisting of five questions was filled out by the participants three times i.e. before the trips, after the museum visit and after the scientific field trip. The data obtained from the opinion form were coded and the frequencies were determined before the trip, after the museum visit and after the scientific field trip. When evaluated in general, in the codes obtained from the opinion data belonging to prospective teachers quite low frequencies were reported before the trips. When the findings out of the opinions of the prospective biology teachers regarding the contributions of the outdoor learning environments were studied, it was figured out that the codes of gaining new information, observation, permanent learning, socializing, learning through having fun bore commonalities before and after the trips. After the trips, it was determined that the prospective teachers used codes such as providing sample diversity, impressive learning, being a teacher, new experiences, and concretization of the information. Bostan Sarığlu and Küçüker (2017) found that prospective science teachers had the view that outdoor learning environments attracted the attention of the students, provided permanent learning, and were more related to daily life. In their studies, Mertoğlu (2019), Balkan Kıyıc1 and Atabek Yiğit (2010) found that prospective science teachers realized learning by seeingliving-having fun and learning permanent learning; gained experience through their own lives and attained new information as a result of their activities in outdoor learning environments. It was also stated that, through this experience, prospective teachers' self-confidence increased in professional means and they declared they would like to conduct activities in outdoor learning environments with their students when they became teachers. In the study conducted by Karademir (2013) in eight universities, it was found that prospective primary school and science teachers uttered that the course was enriched, learning became easier and enjoyable with outdoor activities. In parallel to these studies, Uzel, Çıkrık, Yel and Gül (2019) pinpointed that prospective biology teachers had higher self-efficacy beliefs in organizing the trips. These studies conducted with prospective teachers support the results of the current study.

Sontay, Tutar and Karamustafaoğlu (2016) and Demir and Öner Armağan (2018), who had a planetarium trip with students studying in different classes, found that students' interest in science lessons increased after the trip, knowledge became permanent, and that outdoor learning environments were fun. Similarly, Erten and Taşçi (2016) underpinned that observational and defining operational skills of the fifth grade students improved with outdoor learning environments. The study by Randler, Kummer and Wilhelm (2012) proved that students who were taken to the zoo had demonstrated increased levels of learning and there was more permanent information. Bakioğlu and Karamustafaoğlu (2014) underscored that students learned the subject in the curriculum in detail at first hand, and the studies by Y1ldirim (2020) and Rowe and Nickels (2011) reached the conclusion that out-of-school learning environments enhanced student motivation. In addition to these, Chin (2004) found out that after the museum visit, it became easier for students to associate their knowledge learned at school with real life. Bakioglu et al. (2018) also found that out-of-school learning environments positively affect student success. These studies indicate similar results to the results of the present study. When the studies conducted with teachers on outdoor learning environments were examined, SelanikAy and Erbasan (2016) emphasized that outdoor learning environments provided permanent 
learning and increased student interest and sociability, according to the opinions of teachers they received in their study. Ocak and Korkmaz (2018) found that teachers had the view that outdoor learning environments offered permanent learning, concretized students' soft information, and made positive contributions to their development. Likewise, Tatar and Bağrıyanık (2012) accentuated that the reasons for the majority of teachers' preference for learning activities out of school was that students learned by doing and living, and the activities were effective in increasing students' interest, eagerness, and curiosity. In the study by Türkmen (2015), teachers expressed that field trips provided permanent learning, but trips could not be made due to certain reasons such as cost, lack of suitable environment, bureaucratic problems and the intensity of the curriculum. It is understood from the studies conducted with teachers that the contributions of outdoor school learning environments are quite similar to the results of this research.

When the results of this study are examined, it is comprehended that the frequencies of the prospective teachers for providing sample diversity, being impressive and concretizing the information are high, especially after the museum visit. Likewise, as a result of their studies, Selanik-Ay and Kurtdede Fidan (2014) announced prospective teachers believed that benefiting from museums contributed the most to the permanence of what had been learned and to concretization of some concepts. On the other hand, Karadeniz and Okvuran (2014) uttered their opinions in their studies with prospective teachers that the activities they carried out increased students' level of curiosity and attention, were fun and instructive, offered permanent learning, and helped them build awareness of cultural heritage and intercultural interaction.

In this study, it was seen that, depending on the content of the trip, prospective biology teachers emphasized such codes as providing sample diversity, learning in the natural environment, concretizing the information, and learning by doing and living after the scientific field trip. In a similar manner, in their study conducted with prospective biology teachers, Y1ldiz, Baykal and Altın (2002) observed that after the field trips, prospective teachers' theoretical knowledge was reinforced, misinformation was corrected and their interest and curiosity increased due to the richness of the species encountered during the trip. Doğan, Çiçek and Saraç (2018) stated that prospective science teachers' participating in the field trip increased the permanence of the novel information they were presented with, and the trip enabled them to associate with daily life, carry out observations on the related subject and transferred theoretical knowledge into practice, increased their motivation, and improved their psychomotor skills. Aytaç (2014) reached the conclusion that prospective social science teachers easily understood geography subjects and increased their success in their lessons with the trip observation method.

When the opinions of the prospective biology teachers about the things to be done during the planning, implementation and evaluation of outdoor learning environments are taken into consideration, it is concluded that the codes such as obtaining permission, arranging the vehicle, getting the students prepared, preparing the equipment, group cohesiveness and practice came to the fore. It may be thought that prospective teachers, who had more general perspectives before the trips, realized after the trips that the preliminary preparations, implementation, and evaluation were important. In order for these basic stages to be gone through efficiently, apparently a good trip should proceed based on the plan and with discipline and harmony. In the study by Ocak and Korkmaz (2018), teachers articulated that ensuring security, obtaining permission from administration and parents, and student and parent involvement were crucial in the planning stage of outdoor learning environment. Kisa and Gazel (2016) found in their research that teachers informed students about museum rules previously, before the museum visit. In addition to that, it was found that teachers with professional experience of 11 years or 
more attached more importance to museum visits since they see the information obtained there as more permanent.

In the current study, prospective biology teachers emphasized that it was necessary for students to come prepared with having the required equipment especially in the planning of the scientific field trip. During an observation trip, the equipment that teachers and students should have with them can increase the success of teachers and students during the implementation and provides the opportunity of having a nice trip. Each trip is unique. Therefore, it is natural for the materials to be used in every single trip to change and to be customized/tailor made. The clothes that students and teachers will wear on the day of the trip are also essential for the efficiency of the trip for students cannot devote themselves to a trip which does not offer comfortable experiences (situations where they feel cold, sweat, and cannot move, etc.) so they cannot reach the aims of the trip (Demir, 2007). During the implementation phase of the research, it was seen that the code of following the guide / teacher came to the fore in particular after the museum visit and the code of practice after the scientific field trip, depending on the content of the trip. Parallel to this, Shaby, Ben-Zvi Assaraf and Tal (2019) underlined that effective communication between museum educators and students will allow students to improve their experiences in museum visits. In their research conducted with preschool teachers about the museum visit, Akman et al. (2015) determined that the teachers focused on preliminary information about the museum and museum rules during the preparation phase. Also, according to teachers, the museum trip provided students with the opportunities to make observations, acquire information about works of art, make explanations, and take photographs. After the museum visit, the teachers said that they wanted the students to express what they saw, how they felt, and to share the things they showed interest in during the trip, to paint and to revive what they witnessed in the museum.

In the evaluation phase, prospective biology teachers stated that, especially after the trips, taking students' opinions and employing question-answer method was necessary. In addition, prospective teachers expressed their opinions regarding the examination of the notes, photos, samples, and so on after the scientific field trip. Çetin, Kuş and Karatekin (2010) found that teachers mostly used in-class activities like written and verbal narration and drawing pictures about the trip for assessment purposes. Very few of the teachers had their students organize a photography exhibition and watched some relevant videos after the trip. In a study conducted with teachers, Yildırım (2012) determined that teachers mostly used verbal expression activity (discussion, question-answer), and visual expression (drawing) and form filling activities were extraordinarily less the trip.

When the opinions of the prospective biology teachers with respect to the more effective use of outdoor learning environments were checked, it was understood that a good trip plan, determination of its content and time management came to the fore. In the content dimension, prospective teachers highlighted the issues of giving detailed information along with preliminary information, and depending on the content of the trip, they emphasized the issues of observation and investigation. In the time management dimension, in line with the content of the trip, prospective teachers mentioned allowing free time on the museum trip and the importance of day selection in the field trip. Similarly, Aslan (2019) found in his study with prospective teachers that they focused on acquiring information from the expert and choosing the place to have a more effective field trip. It was also determined that field trips contributed to the permanence of the course information and provided more detailed data. In the study by Yener et al. (2018), which was conducted with prospective teachers about science trips, prospective teachers advocated that the trip should be accompanied by a guide and students 
should receive preliminary information. Also, in their views after the trip, they emphasized such issues as organizing the trip in small groups, using time efficiently, and students' themselves taking some notes. While prospective teachers emphasized gaining new information the most about the scientific trip before the museum visit, they emphasized the notion of permanent learning the most after the trip. They stated in their views after the museum visit that the science trip was effective in regard to socializing and developing communication, consciousness, and awareness raising. Karamustafaoğlu, Ayval1, Ocak (2018) claim that in order for preschool teachers to organize more effective out-of-school activities, it is fundamental to pay attention to individual activities and individual differences in learning by doing and living more, to adapt the environment to learner level, to make the necessary physical arrangements, and to ensure the active participation of learners. In their study conducted with seventh grade students with a factory trip, Bozdoğan, Okur and Kasap (2015) proclaim that the trip should be planned well, it has a high permanence when the information is gained by doing and living, and that it is interesting and intriguing, and gives the opportunity to observe. In their study with teachers, Malkoç and Kaya (2015) found that such factors as the content of the course, the appropriateness of the physical structure and time were effective in the use of school environments outside the classroom. It was also recorded that factors such as insufficient physical structure of the school, density of the program, planning problems, lack of time and class sizes were influential in not using these environments.

In this research, museum visit and scientific field trip were used to determine the opinions of prospective biology teachers about outdoor learning environments. According to the findings of the research, it has been concluded that the trips contribute positively to the learning of the teacher candidates, notwithstanding, there are points to be considered during the planning, implementation and evaluation stages of the trips and there are also items recommended for more effective trips. Taking into consideration the number of participants in this study, which uses a qualitative model, the generalizability is low. For this reason, new studies are proposed, which are supported by large samples and quantitative data collection methods.

\section{References}

Akman, B., Özen Altınkaynak, Ş., Ertürk Kara, H.G., \& Can Gül, Ş. (2015). The views of preschool teachers on museum education. Journal of Uludag University Faculty of Education, 28(1), 97-115.

Aktın, K. (2017). Development of the historical thinking skills of children with museum education in pre-school period. Mersin University Journal of the Faculty of Education, 13(2), 465-486.

Arianti, Y., \& Aminatun, T. (2019). An analysis of outdoor learning towards students' outcomes in learning biology. The International Seminar on Bioscience and Biological Education, Journal of Physics: Conference Series, 1241, 1-6. doi:10.1088/1742$6596 / 1241 / 1 / 012061$

Aslan, A. (2019). Determination of prospective teachers' attitudes on scientific field trips and views on hydroelectric power plants. Journal of Research in Informal Environments, 4(1), 61-83.

Aytaç, A. (2014). The place and importance of the field trip method for the social science teacher candidates education. Journal of Hasan Ali Yücel Education Faculty, 11(21), 55-69.

Bakioglu, B., Karamustafaoglu, O., Karamustafaoglu, S., \& Yapici, S. (2018). The effects of out-of-school learning settings science activities on 5th graders' academic achievement. European Journal of Educational Research, 7(3), 451-464. 
Bakioğlu, B., \& Karamustafaoğlu, O. (2014). Outdoor science education: Technical visit to a dialysis center. Turkish Journal of Teacher Education, 3(2), 15-26.

Balkan Kıyıc1, F., \& Atabek Yiğit, E. (2010). Science education beyond the classroom: A field trip to wind power plant. International Online Journal of Educational Sciences, 2(1), 225-243.

Bostan Sarığlu, A., \& Küçüker, H. (2017). Investigation of preservice science teachers' opinions regarded to outdoor school learning environments. Journal of Research in Informal Environments, 2(1), 1-15.

Bozdoğan, A.E., Okur, A., \& Kasap, G. (2015). A sample application for a planned field trip: A factory trip. The Black Sea Journal of Social Sciences, 7(2), 1-12.

Braund, M., \& Reiss, M. (2006). Towards a more authentic science curriculum: The contribution of out-of-school learning. International Journal of Science Education, 28, 1373-1388.

Bülbül, H. (2016). Creating cultural heritage consciousness on middle school students through museum education. ODU Journal of Social Science Research, 6(3), 681-694.

Büyüköztürk, Ş., Kılıç Çakmak, E., Akgün Ö.E., Karadeniz, Ş., \& Demirel, F. (2012). Scientific research methods. Ankara: Pegem Publication.

Chin, C-C. (2004). Museum experience: A resource for science teacher education. International Journal of Science and Mathematics Education, 2, 63-90.

Creswell, J.W. (1994). Research design: Qualitative and quantitative approaches. Thousand Oaks: Sage Publications.

Creswell, J.W. (2013). Nitel araştırma yöntemleri [Qualitative inquiry \& Research design] (Trans.Eds.: M. Bütün \& S.B. Demir). Ankara: Siyasal.

Çavuş, R., Umdu Topsakal, Ü., \& Öztuna Kaplan, A. (2013). Teachers views' on awareness of environmental acquiring in informal learning environments: The sample of Kocaeli science houses. Pegem Journal of Education and Instruction, 3(1), 15-26.

Çetin, T., Kuş, Z., \& Karatekin, K. (2010). Opinions of class and social sciences teachers about trip-observation method. Gaziosmanpaşa University Social Sciences Research Journal, 5(2), 158-180.

Demir, M.K. (2007). The study of classroom teacher candidates' perspectives towards field trip method. Gazi University Journal of Gazi Educational Faculty, 27(3), 83-98.

Demir, N., \& Öner Armağan, F. (2018). Views of the secondary school students towards planetariums. The Journal of International Education Science, 18, 118-131.

Dillon, J., Rickinson, M., Teamey, K., Morris, M., Choi, M.Y., Sanders, D., \& Benefield, P. (2006). The value of outdoor learning: Evidence from research in the UK and elsewhere. School Science Review, 87(320), 107-111.

Doğan, Y., Çiçek, Ö., \& Saraç, E. (2018). The field trip experiences of pre-service science teachers in the environmental science course. Erzincan University Journal of Education Faculty, 20(1), 104-120.

Ekiz, D. (2013). Scientific research methods. Ankara: An1 Publication.

Erten, Z., \& Taşçi, G. (2016). Developing activities of out of the school learning environments for science classes, and analysing their effects on students' scientific process skills. Erzincan University Journal of Education Faculty, 18(2), 638-657.

Fidan, N. (2012). Okulda öğrenme ve öğretme [Learning and teaching at school]. Ankara: Pegem Publication.

Karademir, E. (2013). Öğretmen ve ögretmen adaylarının fen ve teknoloji dersi kapsamında "okul dışı öğrenme etkinliklerini" gerçekleştirme amaçlarının planlanmış davranış teorisi yoluyla belirlenmesi [Determination of Objectives Realization at Outdoor Science Education Activities of Teachers and Pre-Service Teachers by the Theory of Planned Behavior Within the Scope of Science and Technology Lesson, Dissertation]. 
(Unpublished Doctoral Thesis). Hacettepe University, The Institute of Social Sciences, Ankara.

Karadeniz, C., \& Okvuran, A. (2014). A night at the museum: Museum education with Ankara University students at Çorum Museum of Archeology. Elementary Education Online, 13(3), 865-879.

Karamustafaoğlu, S., Ayvalı, L., \& Ocak, Y. (2018). Teachers' opinions on informal environments in pre-school education. Journal of Research in Informal Environments, $3(2), 38-65$.

Kisa, Y., \& Gazel, A.A. (2016). Social studies teacher and student evaluation of teaching museum of use of opinions (Museums Afyonkarahisar). International Journal of Field Education, 2(1), 51-83.

Malkoç, S., \& Kaya, E. (2015). The usage of non-classroom environments in social studies education. Elementary Education Online, 14(3), 1079-1095.

Mertoğlu, H. (2019). Opinions of science pre-service teachers on out-of-school activities conducted in different learning environments. Journal of Research in Informal Environments, 4(1), 37-60.

Miles, M.B., \& Huberman, A.M. (1994). Qualitative data analysis (2 ${ }^{\text {nd }}$ Edition). Thousand Oaks: Sage Publications.

Moustakas, C. (1994). Phenomenological research methods. Thousand Oaks: Sage Publications.

MTA (2019). MTA Şehit Cuma Dağ Natural History Museum. Retrieved July 31, 2019 from: http://www.mta.gov.tr/v3.0/sayfalar/muze/egitim-birimi/muzemizi-gezelim/

Nicol, R. (2002). Outdoor education: Research topic or universal value? Part one. Journal of Adventure Education and Outdoor Learning, 2, 29-41.

Ocak, İ., \& Korkmaz, Ç. (2018). An examination of the views of science and pre-school teachers on non-formal learning environments. International Journal of Field Education, 4(1), 18-38.

Okur-Berberoğlu, E., \& Uygun, S. (2013). Examining of outdoor education development in the world and in Turkey. Mersin University Journal of the Faculty of Education, 9(2), 3242.

Randler, C., Kummer, B., \& Wilhelm, C. (2012). Adolescent learning in the zoo: Embedding a non-formal learning environment to teach formal aspects of vertebrate biology. Journal of Science Education and Technology, 21(3), 384-391.

Rowe, S., \& Nickels, A. (2011). Visitor motivations across three informal education institutions: An application of the identity-related visitor motivation model. Visitor Studies, 14(2), 162-175.

Saraç, H. (2017). Researches related to outdoor learning environments in Turkey: Content analysis study. Journal of Education Theory and Practical Research, 3(2), 60-81.

Selanik-Ay, T., \& Erbasan, Ö. (2016). Views of classroom teachers about the use of out of school learning environments. Journal of Education and Future, 10, 35-50.

Selanik-Ay, T., \& Kurtdede Fidan, N. (2014). Teacher candidates' views about using museums in social studies education. Electronic Journal of Social Sciences, 13(48), 69-89.

Shaby, N., Ben-Zvi Assaraf, O., \& Tal, T. (2019). An examination of the interactions between museum educators and students on a school visit to science museum. Journal of Research in Science Teaching, 56(2), 211-239.

Sontay, G., Tutar, M., \& Karamustafaoğlu, O. (2016). Student views about "Science teaching with outdoor learning environments": Planetarium tour. Journal of Research in Informal Environments, 1(1), 1-24. 
Szczepanski, A., Malmer, K., Nelson, N., \& Dahlgren, L.O. (2007). The distinctive nature and potential of outdoor education from a teacher's perspective: An intervention study of teachers in school. Didaktisk Tidskrift, 16, 89-106.

Tatar, N., \& Bağriyanık, K.E. (2012). Opinions of science and technology teachers about outdoor education. Elementary Education Online, 11(4), 883-896.

Thomas, G. (2015). Signature pedagogies in outdoor education. Asia-Pacific Journal of Health, Sport and Physical Education, 6(2), 113-126.

Türkmen, Ç. (2010). İnformal (sınıf-dışı) fen bilgisi eğitimine tarihsel bakış ve eğitimimize entegrasyonu [Historical view of informal (out-of-class) science education and its integration into our education]. Cukurova University Faculty of Education Journal, 39, 46-59.

Türkmen, H. (2015). Primary teachers point of view about science teaching in outdoor learning environments. Journal of European Education, 5(2), 47-55.

Uzel, N., Çıkrık, S., Yel, M., \& Gül, A. (2019, June). Biyoloji öğretmen adaylarının okul dışı çevrelere eğitim amaçlı gezi düzenleyebilmesine ilişkin öz-yeterlik inançları [Selfefficacy beliefs about biology teacher candidates' organizing educational trips out of school environments]. V. TURKCESS International Education and Social Sciences Congress, İstanbul.

Van Dijk-Wesselius, J.E., Van Den Berg, A.E., Maas, J., \& Hovinga, D. (2020). Green schoolyards as outdoor learning environments: Barriers and solutions as experienced by primary school teachers. Frontier in Psychology, 10. https://doi.org/10.3389/fpsyg.2019.02919

Yener, D., Aksüt, P., Kiras, B., \& Yener, Y. (2018). Pre-service science teachers' opinions about science trip and Science-Technology-Society-Environment: "The example of science in museum". Başkent University Journal of Education, 5(2), 212-224.

Yıldız, K., Baykal, T., \& Altın, M. (2002). A model study on wetlands for the environment to be better known and its importance to be recognized. Gazi University Journal of Gazi Educational Faculty, 22(3), 1-9.

Yıldırım, A., \& Şimşek, H. (2013). Sosyal bilimlerde nitel araştırma yöntemleri [Qualitative research methods in the social sciences]. Ankara: Seçkin Publication.

Yildırım, H.I. (2020). The effect of using out-of-school learning environments in science teaching on motivation for learning science. Participatory Educational Research (PER), 7(1), 143-161.

Yıldırım, R. (2012). İlköğretim II. kademe sosyal bilgiler derslerinde gezi-gözlem yönteminin uygulanma durumunun incelenmesi [Study of application for excursion observation method in primary school $2^{\text {nd }}$ grade social studies]. (Unpublished Master's Thesis). Afyon Kocatepe University, The Institute of Social Sciences, Afyonkarahisar. 


\section{Appendix 1}

Opinion Form of Prospective Biology Teachers about Outdoor Learning Environments

1. What are the contributions of outdoor learning environments to you?

2. What are the things to be done when planning outdoor learning environments?

3. What are the things to be done during the implementation of outdoor learning environments?

4. What are the things to be done at the evaluation stage of outdoor learning environments?

5. What are your suggestions for more effective use of outdoor learning environments?

Opinion Form of Prospective Biology Teachers about Outdoor Learning Environments (Museum Visit)

1. What are the contributions of the museum visit to you?

2. What are the things to be done at the planning stage of your museum visit?

3. What are the things to be done during the implementation of the museum visit you have done?

4. What are the things to be done at the evaluation stage of your museum visit?

5. What are your suggestions to make the museum visit more effective?

Opinion Form of Prospective Biology Teachers about Outdoor Learning Environments (Scientific Field Trip)

1. What are the contributions of the scientific field trip to you?

2. What are the things to be done at the planning stage of your scientific field trip?

3. What are the things to be done during the implementation of the scientific field trip you have done?

4. What are the things to be done at the evaluation stage of your scientific field trip?

5. What are your suggestions to make the scientific field trip more effective? 